\title{
Secretion of Tyrosinase in Streptomyces glaucescens
}

\author{
By R. CRAMERI, ${ }^{1}$ L. ETTLINGER, ${ }^{1}$ R. HÜTTER,${ }^{1 *} \mathrm{~K}$. LERCH, ${ }^{2}$ \\ M. A. SUTER ${ }^{1}$ AND J.A. VETTERLI ${ }^{1}$ \\ ${ }^{1}$ Mikrobiologisches Institut, Eidgenössische Technische Hochschule, ETH-Zentrum, \\ CH-8092 Zürich, Switzerland \\ ${ }^{2}$ Biochemisches Institut der Universität Zürich, Zürichbergstrasse 4, CH-8032 Zürich, \\ Switzerland
}

(Received 9 March 1981; revised 30 June 1981)

\begin{abstract}
In Streptomyces glaucescens, the intracellular and the extracellular enzyme forms of tyrosinase were found to be identical in molecular weight (29000), in copper content $(0.21 \%)$, in the 19 amino acids at the amino-terminal end and in the ratio of cresolase to catecholase activity $(0.005)$. The tyrosinase secretion process exhibited a constant rate of 0.15 units $\mathrm{h}^{-1}$ (mg protein $)^{-1}$. Under highly induced conditions intracellular tyrosinase was accumulated. Mutations responsible for the non-melanogenic, tyrosinase-positive non-secretor mutant type are located chromosomally on the upper right arc of the $S$. glaucescens map near the ade- $I$ marker.
\end{abstract}

\section{INTRODUCTION}

The capacity to form melanin-like pigments is widely distributed among streptomycetes. The physiological conditions stimulating the phenotypic expression of the character have been studied by several authors (see Arai \& Mikami, 1972; Küster, 1976). It was observed that complex media containing peptone or tryptone are favourable for melanin formation and that in chemically defined media the addition of specific amino acids besides L-tyrosine is frequently necessary to provoke a clear-cut response. As demonstrated for Streptomyces glaucescens strain ETH 22794, the addition of specific amino acids leads to an induction of the synthesis of tyrosinase (EC 1.14.18.1), the enzyme responsible for the oxidation of the substrate L-tyrosine (Lerch \& Ettlinger, 1972; Baumann \& Kocher, 1976). In different Streptomyces strains different amino acids are necessary for enzyme induction (M. Wyss, unpublished results).

Under most laboratory conditions tyrosinase can be present intracellularly as well as extracellularly (Baumann \& Kocher, 1976). Two classes of melanin-negative (mel) mutant strains have been isolated. Mutant strains lacking tyrosinase activity completely were designated class I, whereas those normal with respect to the capacity to form tyrosinase and with respect to the induction process, but defective in enzyme secretion were designated class II (Baumann \& Kocher, 1976; Baumann et al., 1976). Preliminary genetic experiments did not indicate a fixed chromosomal location of the class II mutant type (Baumann \& Kocher, 1976), while the class I mutations mostly mapped chromosomally (Hütter et al., 1981). These results contrast with the finding in Streptomyces scabies of extrachromosomal inheritance of tyrosinase formation (Gregory \& Shyu, 1961; Gregory \& Huang, $1964 a, b$ ).

This paper characterizes the process of tyrosinase secretion in $S$. glaucescens by an analysis of the dynamics of the secretion process and by the characterization of the secreted enzyme. Mutant strains defective in the secretion process were investigated to clarify the genetic position of the mutations responsible for this phenotype. 


\section{METHODS}

Organisms. The wild-type strain GLA0 of Streptomyces glaucescens corresponds to strain ETH 22794 described previously (Hütter, 1967; Baumann et al., 1974). The non-secretor mutant strains GLA15B, GLA21 and GLA62 were described by Baumann et al. (1976) and Suter (1978). The mutant strains GLA94 and GLA567 used for genetic mapping were recombinant strains derived by crosses according to the method of Baumann et al. (1974).

The strains were grown on agar slants at $30^{\circ} \mathrm{C}$ for 4 to $10 \mathrm{~d}$ until abundant sporulation had occurred. The wild-type strain was stored at $4{ }^{\circ} \mathrm{C}$; the melanin-negative mutant strains were stored at room temperature, as they did not survive well at $4{ }^{\circ} \mathrm{C}$.

Media. Minimal medium for solid culture was as follows: glucose, $10 \mathrm{~g}$; L-asparagine, $0.5 \mathrm{~g} ; \mathrm{MgSO}_{4} \cdot 7 \mathrm{H}_{2} \mathrm{O}$, $0.2 \mathrm{~g}: \mathrm{K}_{2} \mathrm{HPO}_{4} \cdot 3 \mathrm{H}_{2} \mathrm{O}, 0.5 \mathrm{~g}$; $\mathrm{CuSO}_{4} .5 \mathrm{H}_{2} \mathrm{O}, 10 \mathrm{mg}: \mathrm{FeSO}_{4} .7 \mathrm{H}_{2} \mathrm{O}, 10 \mathrm{mg} ; \mathrm{KOH}(3 \%, \mathrm{w} / \mathrm{v}), 3 \mathrm{ml}$; agar, $15 \mathrm{~g}$; deionized water, $1000 \mathrm{ml}$. The agar was dissolved in $700 \mathrm{ml}$ water and steamed for $1 \mathrm{~h}$; the remaining solid ingredients were dissolved in $300 \mathrm{ml}$ water and the $\mathrm{KOH}$ was added after the dissolution of the salts. The two component solutions were mixed and autoclaved for $20 \mathrm{~min}$ at $120^{\circ} \mathrm{C}$. For auxotrophically marked strains the media were supplemented with the necessary amino acids or vitamins just before pouring of the slants or plates (final concentration: $100 \mathrm{mg}^{-1}$ for amino acids or $2 \mathrm{mg} \mathrm{l}^{-1}$ for vitamins). The amino acids and vitamins were maintained as separate stock solutions and were sterilized by filtration. Streptomycin sulphate, also maintained as a separate stock solution sterilized by filtration, was added to a final concentration of $150 \mathrm{mg} \mathrm{l}^{-1}$ where necessary. To bring about melanin formation the medium was supplemented with $2 \mathrm{mM}$-L-tyrosine and, where desirable, 10 mM-L-methionine as inducer of tyrosinase (Baumann \& Kocher. 1976). Tyrosinase-secreting colonies can be detected on this medium by the formation of black melanin haloes after incubation for $5 \mathrm{~d}$ at $30^{\circ} \mathrm{C}$.

For liquid cultures a sodium glutamate minimal medium described by Baumann \& Kocher (1976) was used. For mutant strains amino acids or vitamins were added separately as indicated above. To indicate tyrosinase formation the media were supplemented with $2 \mathrm{mM}$-L-tyrosine.

Cultivation conditions. Spore suspensions were prepared from agar slants by adding $10 \mathrm{ml}$ of sterile deionized water and carefully scraping the surface of the agar with an inoculation needle. The resulting suspension contained about $5 \times 10^{8}$ spores $\mathrm{ml}^{-1}$. If the suspension contained more than $10 \%$ mycelial fragments it was filtered through loosely packed sterilized cotton plugs.

Cultures in liquid media were grown in 1 litre Erlenmeyer flasks containing $400 \mathrm{ml}$ medium, or in $100 \mathrm{ml}$ Erlenmeyer flasks containing $20 \mathrm{ml}$ medium. In both cases, media were inoculated to a concentration of about $2 \times$ $10^{5}$ spores $\mathrm{ml}^{-1}$ and the cultures were incubated at $30^{\circ} \mathrm{C}$ on rotary shakers $\left(120 \mathrm{rev} . \mathrm{min}^{-1}\right)$.

Determination of growth (wet weight) and total protein. Culture suspensions $(50 \mathrm{ml})$ were filtered through a filter paper (no. $589^{2}, 5.5 \mathrm{~cm}$; Schleicher and Schuell, Feldmeilen ZH. Switzerland) and washed twice with deionized water. During the washing process the mycelium had frequently to be loosened to avoid clogging of the filter. The mycelium retained was removed from the filter and weighed.

Total protein was determined by the biuret method according to Herbert et al. (1971). Culture suspensions $(5 \mathrm{ml})$ were filtered through a glass filter (type GF/C, $2.4 \mathrm{~cm}$ : Whatman) and the filter cake was washed twice with deionized water. The mycelium was hydrolysed prior to the biuret reaction with $3 \mathrm{ml} 3 \mathrm{M}-\mathrm{NaOH}$ for 10 min at $100^{\circ} \mathrm{C}$.

One $\mathrm{mg}$ of wet mycelium corresponded to $0.13 \mathrm{mg}$ total protein.

Preparation of crude extracts. Mycelium, harvested as for the determination of the wet weight. was suspended at $10 \%(\mathrm{w} / \mathrm{v})$ in $0.05 \mathrm{M}$-sodium phosphate buffer, $\mathrm{pH} 7.5$. The mycelium was then broken by ultrasonic treatment (MSE $150 \mathrm{~W}$ ultrasonic disintegrator). Sonication periods were $10 \mathrm{~s}$ and were interrupted by cooling of the suspension in ice/water. The length and intensity of the treatment were adjusted to the suspension volume; a minimal treatment time and intensity were attempted and the disintegration process was followed under the microscope. Cell debris were removed from the resulting crude extract by centrifugation at $4^{\circ} \mathrm{C}$ for $15 \mathrm{~min}$ at $40000 \mathrm{~g}$.

Determination of enzyme activities. For the determination of tyrosinase (monophenol,dihydroxyphenylalanine : oxygen oxidoreductase; EC 1.14.18.1) usually the catecholase assay was used. Total tyrosinase activity present in a culture was determined as follows. Mycelial suspensions $(2 \mathrm{ml})$ were removed from the culture and subjected immediately to an ultrasonic treatment as indicated above or frozen $\left(-21^{\circ} \mathrm{C}\right)$ before treatment (no differences were found between the two procedures). The ultrasonicated suspension was centrifuged at $4{ }^{\circ} \mathrm{C}$ for 15 $\mathrm{min}$ at $40000 \mathrm{~g}$ and the supernatant was used for the determination of total tyrosinase activity. No activity was detected in the pellet, provided the mycelial fragments were well broken. Extracellular tyrosinase activity was determined in the filtrate prepared as indicated for the determination of growth by the biuret method. Intracellular activity was either calculated as the difference between total and extracellular activity (method I) or measured in centrifuged crude extracts directly (method II). Control experiments showed that method II yielded only about half the intracellular activity of method I. This may be due to partial lysis of cells during the relatively harsh washing process (see above). 
The catecholase activity of tyrosinase was determined with the dopachrome test according to Fox \& Burnett (1958). As substrate a solution of $7 \mathrm{mM}$-L-dihydroxyphenylalanine in $0.1 \mathrm{M}$-sodium phosphate buffer, $\mathrm{pH} 6.0$, was used. The formation of dopachrome was followed spectrophotometrically at $475 \mathrm{~nm}$ and $30^{\circ} \mathrm{C}$. One enzyme unit corresponds to the oxidation of $1 \mu \mathrm{mol} L$-dihydroxyphenylalanine $\min ^{-1}$.

Cresolase activity was determined with $3.3 \mathrm{~mm}$-L-tyrosine methyl ester or $10.7 \mathrm{~mm}$-glycyl-L-tyrosine as substrate in $0.1 \mathrm{M}$-sodium phosphate buffer, $\mathrm{pH} \mathrm{7.0.} \mathrm{The} \mathrm{reaction} \mathrm{was} \mathrm{followed} \mathrm{spectrophotometrically} \mathrm{at} 475 \mathrm{~nm}$ and $30^{\circ} \mathrm{C}$ by the development of reddișh (glycyl-L-tyrosine) or brownish (L-tyrosine methyl ester) products, or with an oxygen electrode. One cresolase unit is defined as the amount of enzyme which causes the consumption of $1 \mu \mathrm{mol}$ $\mathrm{O}_{2} \min ^{-1}$.

Protein was determined in the centrifuged crude extracts by the method of Lowry: bovine serum albumin was used as standard. Specific enzyme activities are given as $\mu \mathrm{mol}$ substrate converted or product formed $\mathrm{min}^{-1}(\mathrm{mg}$ protein $)^{-1}$.

Purification of extracellular tyrosinase activity. Extracellular tyrosinase was concentrated from the medium, after removal of the mycelium, by ammonium sulphate treatment ( $70 \%$ saturation). To guarantee efficient precipitation, bovine serum albumin $\left(2 \mathrm{mg} \mathrm{ml}^{-1}\right)$ was added to the filtered medium. The precipitate from 41 medium was dissolved in $20 \mathrm{ml} 5 \mathrm{~mm}$-sodium phosphate buffer, $\mathrm{pH} 7.5$, followed by filtration through Sephadex G-75 (Pharmacia) for removal of salts and of the albumin. To remove melanin pigments, the fractions containing tyrosinase activity were passed through a column $(4 \times 40 \mathrm{~cm})$ of DEAE-cellulose (cellulose DE 52; Whatman) previously equilibrated with $5 \mathrm{~mm}$-sodium phosphate buffer, $\mathrm{pH} 7.5$. Elution of tyrosinase was performed with the same buffer at a flow rate of $50 \mathrm{ml} \mathrm{h}^{-1}$. These treatments led to a 135 -fold purification. For the determination of the amino acid terminal sequence of the extracellular tyrosinase, the partially purified protein was further treated with hydroxyapatite as described by Lerch \& Ettlinger (1972) for the intracellular activity.

Determination of molecular weight. Sodium dodecyl sulphate-polyacrylamide gel electrophoresis was carried out according to Weber \& Osborn (1969) as modified by Crichton \& Bryce (1970). Bovine serum albumin, ovalbumin, pepsin, chymotrypsinogen $A$ and ribonuclease were used as markers for molecular weight determinations.

Determination of amino acid sequence. Automated sequence analysis was performed on a Beckman Sequencer model $890 \mathrm{~B}$ (updated) using the Edman and Begg procedure as modified by Hermodson et al. (1972). The phenylthiohydantoin derivatives were identified by gas chromatography (Hermodson et al., 1972; Pisano et al., 1972), by thin-layer chromatography (Edman \& Begg, 1967; Pisano et al., 1972) and by amino acid analysis after

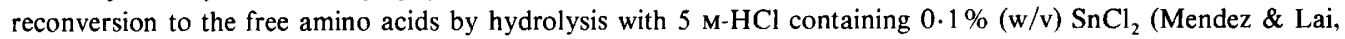
1975). Amino acid analysis was performed on an amino acid analyser (model D-500; Durrum Instruments Corp., Palo Alto, Calif., U.S.A.).

Genetic analysis. Crosses were performed using the method of Hopwood (1967) as described for S. glaucescens by Baumann et al. (1974). Two modifications were introduced: the strains were grown at $37^{\circ} \mathrm{C}$ to ensure better growth and sporulation, and spore suspensions were prepared using a $0.1 \%(\mathrm{v} / \mathrm{v})$ solution of Tween 80 . Map positions were derived using the marker frequency gradient and analysis of Hopwood (1967). The genetic map (Fig. 2) is presented according to Baumann et al. (1974) and Hütter et al. (1981).

\section{RESULTS}

\section{Growth and tyrosinase synthesis in minimal medium}

During growth of the wild-type strain GLA0 in liquid minimal medium (Baumann \& Kocher, 1976) tyrosinase synthesis did not start until about $24 \mathrm{~h}$ after inoculation. Under non-induced conditions only a low extracellular activity of about 0.5 units $\mathrm{ml}^{-1}$ was observed after $2 \mathrm{~d}$ incubation, while the intracellular activity remained below 0.02 units $\mathrm{ml}^{-1}$ during the whole incubation period (data not shown). The minimum detectable intracellular activity (catecholase) was about 0.01 units $\mathrm{ml}^{-1}$. If $10 \mathrm{mM}$-L-methionine was added as inducer after $24 \mathrm{~h}$ preincubation, a marked increase in tyrosinase activity was observed (Fig. $1 \mathrm{a}$ ). The intracellular activity began to increase shortly after addition of the inducer, and at a later stage a marked increase in extracellular activity occurred concomitant with a decrease in intracellular activity. During this major period of secretion, between about 30 and $36 \mathrm{~h}$, the total enzyme activity remained more or less constant around 1.5 units $\mathrm{ml}^{-1}$. After $36 \mathrm{~h}$ a marked decrease in total tyrosinase activity was observed; this may be due to proteolytic destruction of the enzyme. However, no experiments were performed to verify this point.

Considering that $1 \mathrm{mg}$ of wet cell weight corresponds to approximately $10^{-3} \mathrm{ml}$ of cell volume, the maximum cell internal concentration (per total cell volume) of tyrosinase was 


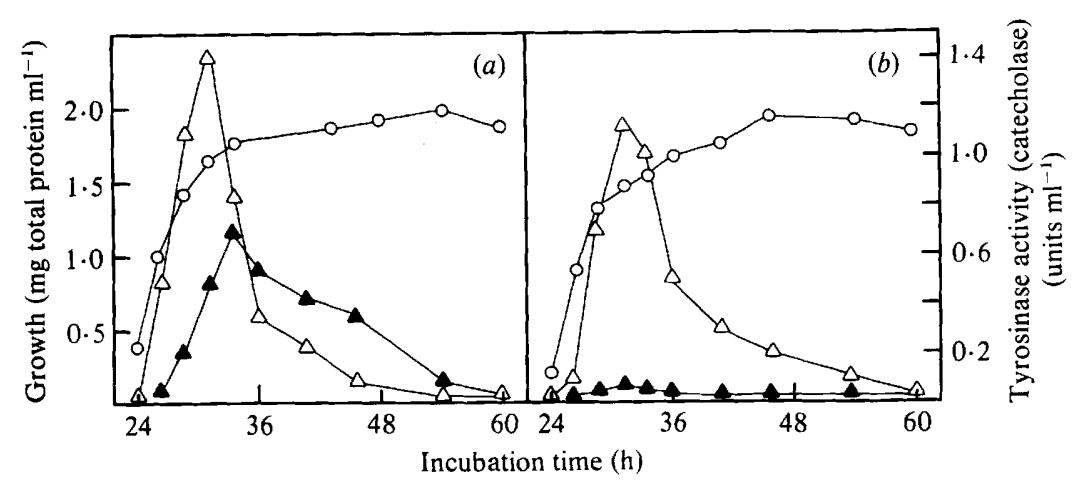

Fig. 1. Tyrosinase formation by $S$. glaucescens strains GLA0 (wild-type) (a) and GLA62 (non-secretor mutant type) (b) after induction with $L$-methionine. The culture was grown in liquid minimal medium for $24 \mathrm{~h}$ as described in Methods. At that time tyrosinase synthesis was induced by the addition of $10 \mathrm{mM}-\mathrm{L}$-methionine. Growth $(\mathrm{O})$, intracellular $(\Delta)$ and extracellular $(\mathbf{\Delta})$ activity were determined as indicated in Methods.

estimated as 600 units $\mathrm{ml}^{-1}$. The maximum rate of tyrosinase synthesis was found to be around 4 units $\mathrm{h}^{-1}$ (mg protein) $)^{-1}$. This rate was reached 2 to $3 \mathrm{~h}$ after the induction (data not shown); in most experiments the value was in the range of 1 to 2 units $^{-1}$ (mg protein) $)^{-1}$ (Fig. 1). The maximum rate of secretion is discussed in more detail below.

\section{Secretion of tyrosinase}

The influence of mycelial mass on the level of enzyme induction and on enzyme secretion was investigated. Low mycelial mass (around $0.2 \mathrm{mg}$ protein $\mathrm{ml}^{-1}$ ) was favourable for induction of the enzyme, while high mycelial mass $\left(0.5\right.$ to $1 \mathrm{mg}$ protein $\left.\mathrm{ml}^{-1}\right)$ was disadvantageous. The total tyrosinase activity $4 \mathrm{~h}$ after induction was between $3 \cdot 5$ and 4 units (mg protein $)^{-1}$ in the former case, but reached only around 1.5 units (mg protein) ${ }^{-1}$ in the latter case. The reduced induction in experiments with high mycelial mass was not due to a rapid disappearance of the inducer L-methionine (data not shown). The rate of tyrosinase secretion was found to be in the range of $0.15 \pm 0.03$ units $h^{-1}$ (mg protein $)^{-1}$ both in cultures induced at low or at high mycelial mass. At the same time, cells induced at low mycelial mass had an intracellular tyrosinase activity of around 1.5 to 2 tyrosinase units $\mathrm{ml}^{-1}$, while those induced at high mycelial mass had an intracellular activity of only around 0.4 units $\mathrm{ml}^{-1}$. Thus, the rate of tyrosinase secretion was not dependent on the pool level of intracellular enzyme, but rather on the mycelial mass or mycelial surface. Furthermore, the rate of tyrosinase secretion was independent of the degree of induction, as long as the rate of induced enzyme synthesis was equal to or higher than the rate of secretion. Under conditions where tyrosinase synthesis was low, the rate of enzyme secretion necessarily decreased and practically all of the tyrosinase synthesized was secreted, as was observed with uninduced cultures.

\section{Identity of the intracellular and extracellular tyrosinase activity}

The intracellular tyrosinase activity has been purified and characterized previously (Lerch \& Ettlinger, 1972). Purification of the extracellular enzyme resulted in a preparation whose molecular properties were indistinguishable from those of the intracellular enzyme. Thus, a molecular weight of 29000 , a copper content of $0.21 \%$ and a cresolase to catecholase activity ratio of 0.005 were observed for the extracellular form, in good agreement with the values reported earlier for the intracellular tyrosinase (Lerch \& Ettlinger, 1972). 
Table 1. Analysis of a multi-factor cross of strains GLA62 lys-2 ura-2 mel-62 × GLA94 hom-1 met-2 pro-1 str-4

\section{Genotype*}

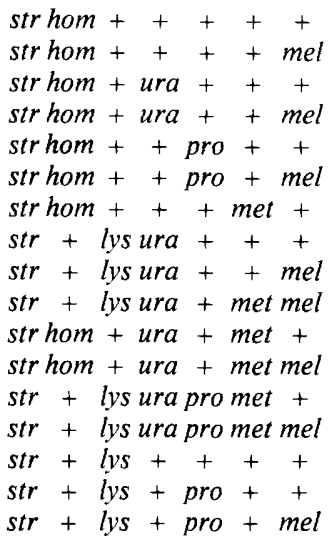

Total

$\begin{array}{cr} & \\ \text { lys }^{+} \text {pro }^{+} & \text {lys }^{+} \text {m } \\ 28 & 0 \\ 11 & 0 \\ 2 & 0 \\ 6 & 0 \\ - & 84 \\ - & 19 \\ 3 & - \\ - & - \\ - & - \\ - & - \\ 48 & - \\ 4 & - \\ - & - \\ - & - \\ - & - \\ - & - \\ - & 103 \\ 102 & -\end{array}$

103
Selection for

$\begin{array}{cccc}\text { met }^{+} & \text {ura }^{+} \text {met }^{+} & \text {str }^{r} \text { hom }^{+} & \begin{array}{c}\text { Crossover } \\ \text { intervals }\end{array} \\ 0 & 2 & - & 4,6 \\ 0 & 0 & - & 4,6 \\ 0 & - & - & 3,6 \\ 0 & - & - & 3,6 \\ 84 & 78 & - & 5,6 \\ 19 & 19 & - & 5,6 \\ - & - & - & 4,5 \\ - & - & 4 & 1,6 \\ - & - & 62 & 1,6 \\ - & - & 1 & 1,5 \\ - & - & - & 3,5 \\ - & - & - & 3,5 \\ - & - & 35 & 1,4 \\ - & - & 1 & 1,4 \\ - & 1 & 1 & 1,3,4,6 \\ - & 1 & 0 & 1,3,5,6 \\ - & 2 & 0 & 1,3,5,6 \\ 103 & 103 & 104 & \end{array}$

${ }^{*}+$, Wild-type alleles; str, streptomycin resistance $\left(>100 \mu \mathrm{g} \mathrm{ml}^{-1}\right)$; mel, non-melanogenic. No str ${ }^{+}$recombinant progeny were found in this particular cross.

+ See diagrams below for intervals. The mel-62 allele is not considered.

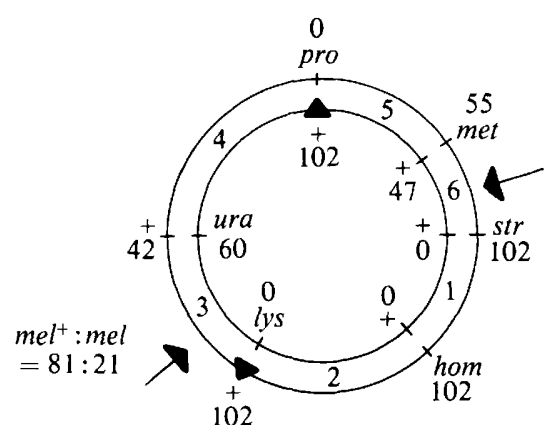

102

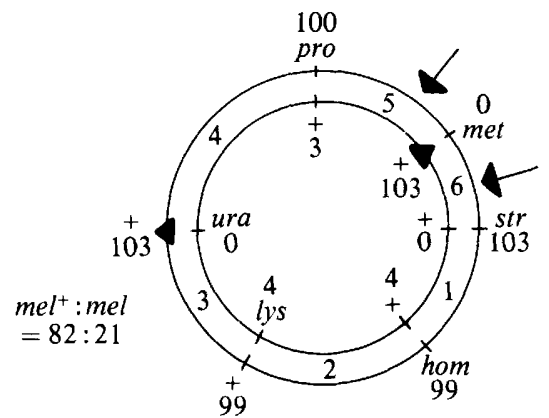

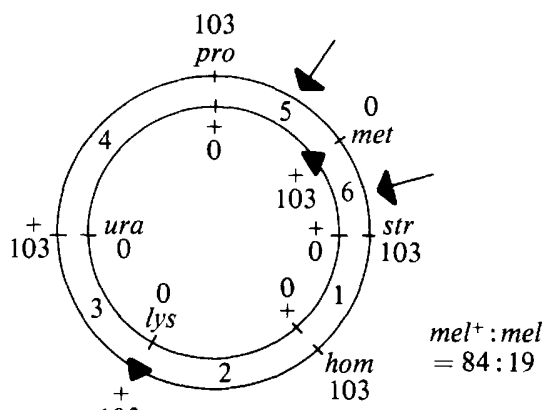

103

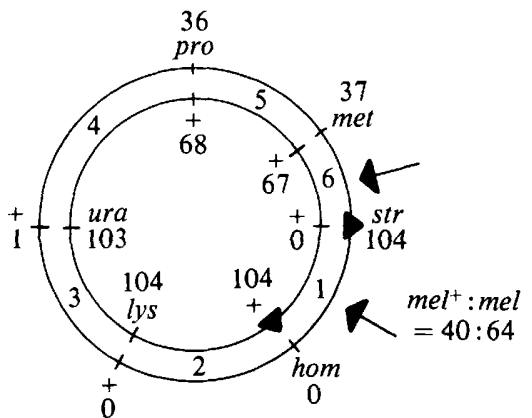

In these diagrams the two circles represent schematically the circular linkage maps of strain GLA62 (inner circles) and strain GLA94 (outer circles), and the triangles indicate the selected alleles. The marker frequencies based on the recombinant progeny analysis are given. The arrows designate possible locations of the mel-62 allele as derived from the marker frequencies.

The identity of the two forms was further corroborated by the determination of the amino-terminal sequences. The primary structure of the first 19 amino-terminal amino acid 
Table 2. Analysis of a multi-factor cross of strains GLA62 lys-2 ura-2 mel-62 × GLA567 rif-567 met-8

\begin{tabular}{|c|c|c|c|c|}
\hline \multirow[b]{2}{*}{ Genotype* } & \multicolumn{3}{|c|}{ Selection for } & \multirow{2}{*}{$\begin{array}{c}\text { Crossover in } \\
\text { intervals } \dagger\end{array}$} \\
\hline & $r i f^{\prime} m^{+} t^{+}$ & $\mathrm{ura}^{+} \mathrm{met}^{+}$ & $l y s^{+} \mathrm{met}^{+}$ & \\
\hline riflys ura + + & 34 & - & - & 1,4 \\
\hline riflys ura + mel & 20 & - & - & 1,4 \\
\hline rif $+u r a++$ & 12 & - & 20 & 2,4 \\
\hline$r i f+u r a+m e l$ & 13 & - & 45 & 2,4 \\
\hline rif ++++ & 18 & 29 & 28 & 3,4 \\
\hline rif +++ mel & 10 & 11 & 13 & 3,4 \\
\hline+++++ & - & 1 & 0 & 1,3 \\
\hline++++ mel & - & 3 & 6 & 1,3 \\
\hline$++u r a+m e l$ & -- & - & 8 & 1,2 \\
\hline+ lys ++ mel & - & 86 & - & 2,3 \\
\hline Total & 107 & 130 & 120 & \\
\hline
\end{tabular}

* + , Wild-type alleles; rif, rifamycin resistance $\left(>100 \mu \mathrm{g} \mathrm{ml}^{-1}\right)$; mel, non-melanogenic.

$\uparrow$ See diagrams below for intervals. The mel-62 allele is not considered.
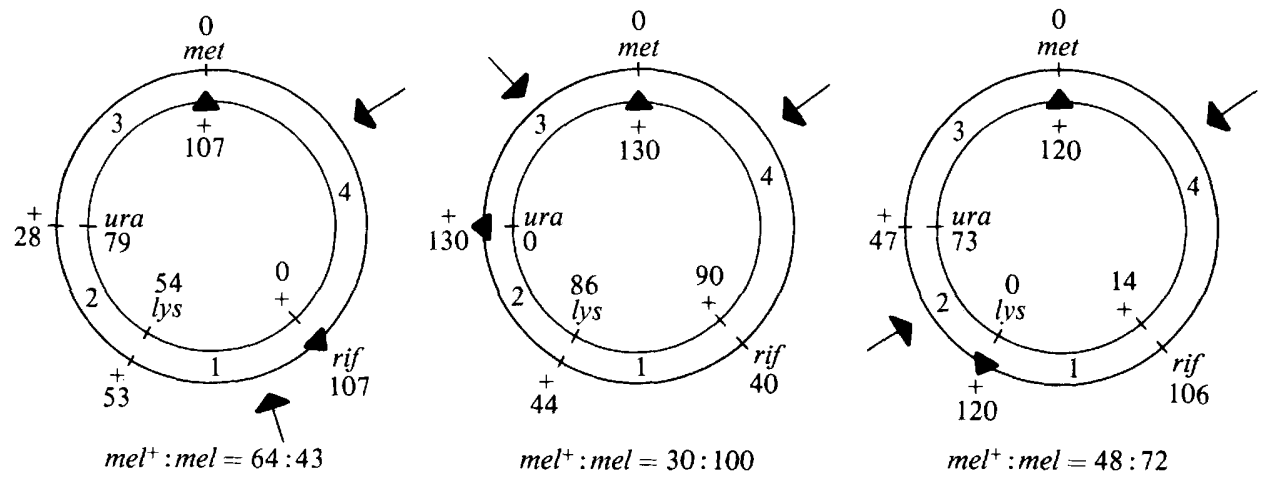

In these diagrams the two circles represent schematically the circular linkage maps of strain GLA62 (inner circles) and strain GLA567 (outer circles), and the triangles indicate the selected alleles. The marker frequencies based on the recombinant progeny analysis are given. The arrows designate possible locations of the mel-62 allele as derived from the marker frequencies.

residues was found to be

Thr-Val-Arg-Lys-Asn-Glu-Ala-Thr-Leu-Thr-Ala-Asp-Glu-Lys-Arg-Arg-Phe-Val-Ala for both the intracellular and the extracellular enzyme.

\section{Mapping of mutant strains defective in tyrosinase secretion}

Of the strains originally described by Baumann \& Kocher (1976) and Suter (1978) several have meanwhile been lost by reversion, but the strains GLA15B, GLA21 and GLA62 still maintain the character described. A typical example of tyrosinase synthesis by a non-secretor mutant type is presented in Fig. $1(b)$.

In previous experiments using mutant strain GLA12 (Baumann \& Kocher, 1976) the mel mutation of class II could not be mapped clearly on the chromosome, but the data obtained were insufficient to postulate with certainty an extrachromosomal location. Therefore, additional efforts were made to map mutant alleles of the non-secretor type. Mapping was primarily performed with the mutant strain GLA62, as this strain carried the most suitable markers. The results of a first cross (Table 1) suggest, on the basis of marker frequency gradients, that mel-62 must be located between str-4 and met-2, as this is the only probable region common to all four selections presented. Also, in the second cross (Table 2), marker 


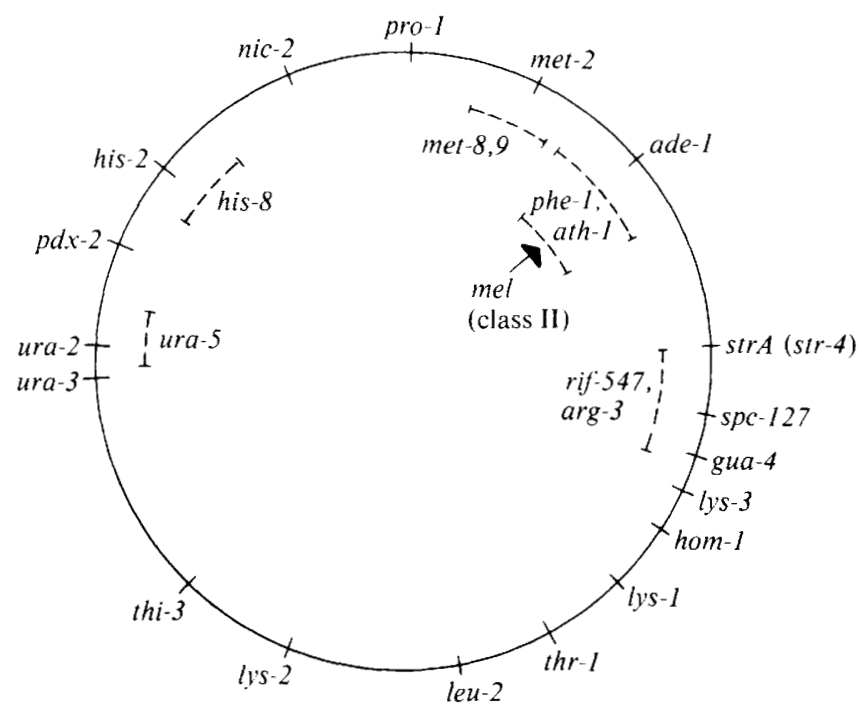

Fig. 2. Genetic map of $S$. glaucescens showing the position of mel mutant alleles of the non-secretor class II.

frequency gradients suggest a location of mel-62 in the upper right arc of the $S$. glaucescens map. For the second cross this location is also favoured by the following data. In the first selection $\left(\mathrm{rif}^{\mathrm{r}} \mathrm{met}^{+}\right.$) all $\mathrm{lys}^{+}$strains should be $\mathrm{mel}^{+}$if $m e \mathrm{l}-62$ were located in the alternative region between rif-567 and lys-2, but 23 are not. In the second selection $\left(\right.$ ura $^{+}$met $^{+}$) all rif $f^{+}$ strains should be $m e l$, and only 3 are not. In the third selection $\left(\mathrm{lys}^{+} \mathrm{met}^{+}\right)$, again, the rif ${ }^{+}$ strains should be mel, but 6 are not; on the other hand, 19 recombinant strains disfavour the interval between $l y s-2$ and $u r a-2$ and 28 strains the interval between ura- 2 and met- 8 .

A final decision as to whether the non-secretor mutant alleles lie above or below ade- 1 (Fig. 2) could not be made, due to the strong linkage observed with ade-l and the lack of sufficient numbers of ade-1 mel-62 recombinants. Similarly, the mel mutations of strains GLA21 and GLA 15B were mapped and also found to be located close to ade-1 (data not shown).

\section{DISCUSSION}

Tyrosinase synthesis in $S$. glaucescens is inducible by a number of amino acids (Baumann $\&$ Kocher, 1976). The enzyme can occur intracellularly and extracellularly. The secretion process did not seem to depend strongly on the level of the intracellular tyrosinase pool, but was found to exhibit a constant rate of about 0.15 units $^{-1}$ (mg protein) $)^{-1}$. This value was maintained as long as the rate of cell internal enzyme synthesis was at least equivalent to the secretion rate. If the rate of synthesis is lower, the secretion rate must necessarily drop by at least the same value. On the other hand, the constant maximum secretion rate limits the export of intracellularly synthesized tyrosinase. Thus, in fully induced cells, where the rate of enzyme synthesis was greater than the maximum secretion rate, a cell internal pool of enzyme was accumulated.

The intracellular and extracellular enzymes were found to be identical in all the parameters tested, namely molecular weight, copper content, enzyme kinetics and amino-terminal amino acid sequence. As shown previously by Kocher (1976), no sugar moieties can be detected in either enzyme form. It can therefore be inferred that the intracellular and extracellular forms do not represent independent enzymes. Such an assumption could also be inferred from the secretion data and from the genetic evidence. Most melanin-negative mutant types isolated are defective in both intracellular and extracellular activity (Baumann et al., 1976; Kieser, 1979; 
Hütter et al., 1981). Thus, the situation is different from that in the fungus Podospora anserina, where multiple phenoloxidases with different characteristics were found (Minuth et al., 1978). To prove the identity of the two forms of the enzyme a complete analysis of the amino acid sequence and possible modifications will be necessary.

The occurrence of identical amino-terminal amino acid sequences in the intracellular and the extracellular forms of the enzyme suggests that no amino-terminal signal sequence is required for transmembrane transfer of tyrosinase. Such signal sequences have been proposed for several secreted proteins (Bassford \& Beckwith, 1979; Bedouelle et al., 1980; Davis \& Tai, 1980; Emr et al., 1980; Marx, 1980). With respect to the non-secretor mel mutant class II we assume, based on preliminary enzyme investigations, that the tyrosinase is unchanged in comparison to the wild-type enzyme and that these mutant strains may be defective in a membrane component essential for tyrosinase secretion. However, purification and detailed analysis of the intracellular enzyme from this mutant class will be necessary to clarify this uncertainty.

Previous results for melanin-negative, tyrosinaseless mutant strains suggested that at least three phenotypically identical, but genetically different mutant subclasses can be differentiated; these mutant types have previously been grouped in the mel class I (Kieser, 1979; Hütter et al., 1981). The non-secretor melanin-negative, tyrosinase-containing mutant strains described here in more detail represent a fourth mutant type involved in melanin biosynthesis. Our data clearly show that representatives of mel class II also map chromosomally. The previous uncertainty (Baumann \& Kocher, 1976; Baumann et al., 1976) was primarily due to experimental difficulties. The Mel II phenotype is frequently not easily detectable in different genetic backgrounds. Differences in growth rate, premature lysis of the cells and the presence or absence of certain auxotrophic markers contribute to these difficulties. In particular, the level of streptomycin resistance in the str-1-carrying strain of Baumann \& Kocher (1976) was insufficient to permit a clear determination of the genotype in all cases, as $S$. glaucescens shows a relatively high level of natural streptomycin resistance (Freeman \& Hopwood, 1978; Hütter et al., 1981). The mutant strains used in this study carried the str-4 allele and were highly resistant to streptomycin, they generally carried markers that did not interfere with tyrosinase formation and they were themselves highly melanogenic. Good melanin production in the partner strains was necessary because the Mel II mutant strains sometimes produced faint brown haloes on medium containing an inducer.

This work was supported by a research grant from the Swiss Federal Institute of Technology, Zürich. Switzerland, and by the Swiss National Science Foundation, grant no. 3.420-0.78 (to K.L.).

\section{REFERENCES}

ARAI, T. \& MiKami, Y. (1972). Chromogenicity of Streptomvces. A pplied Microbiologv 23, 402-406.

Bassford, Рh. \& Beckwith, J. (1979). Escherichia coli mutants accumulating the precursor of a secreted protein in the cytoplasm. Nature, London 277. 538-541.

BaumanN, R. \& Kocher, H. P. (1976). Genetics of Streptomyces glaucescens and regulation of melanin production. In 2nd International Symposium on Genetics of Industrial Microorganisms, pp. 535551. Edited by K. D. Macdonald. London: Academic Press.

BaumanN, R., Hütter, R. \& Hopwood, D. A. (1974). Genetic analysis in a melanin-producing streptomycete, Streptomyces glaucescens. Journal of General Microbiology 81, 463-474.

BaumanN, R., EtTlinger, L., HütTER, R. \& Kocher, H. P. (1976). Control of melanin formation in
Streptomyces glaucescens. In Actinomvcetes: the Boundary Microorganisms, pp. 55-63. Edited by T. Arai. Tokyo: Toppan Co.

Bedouelle, H., Bassford, Ph. J., Fowler, A. V., Zabin, I., Beckwith, J. \& Hofnung, M. (1980). Mutations which alter the function of the signal sequence of the maltose binding protein of Escherichia coli. Nature, London 285, 78-81.

Crichton, R. R. \& Bryce, C. F. A. (1970). Molecular weight estimation of apoferritin sub-units. FEBS Letters 6, 121-124.

Davis, B. D. \& TAI, PH.-C. (1980). The mechanism of protein secretion across membranes. Nature, London 283, 433-438.

Edman, P. \& BegG, G. (1967). A protein sequenator. European Journal of Biochemistry 1, 80-91.

EmR, S. D., Hedgreth, J., Clément, J.-M., Silhavy, T. B. \& Hofnung, M. (1980). Sequence analysis of 
mutations that prevent export of $\lambda$-receptor, an Escherichia coli outer membrane protein. Nature, London 285, 82-85.

Fox, A. S. \& BuRnetT, J. B. (1958). Kinetics of tyrosinase oxidation by crude tyrosinase preparation from Neurospora crassa. Proceedings of the Society for Experimental Biology and Medicine 98, $110-114$.

Freeman, R. F. \& Hopwood, D. A. (1978). Unstable naturally occurring resistance to antibiotics in Streptomyces. Journal of General Microbiology 106, 377-381.

Gregory, K. F. \& HuANG, J. C. C. $(1964 a)$. Tyrosinase inheritance in Streptomyces scabies. I. Genetic recombination. Journal of Bacteriology $\mathbf{8 7}$, 1284-1286.

Gregory, K. F. \& Huang, J. C. C. $(1964 b)$. Tyrosinase inheritance in Streptomyces scabies. II. Induction of tyrosinase deficiency by acridine dyes. Journal of Bacteriology 87, 1287-1294.

Gregory, K. F. \& SHYU, W.-J. (1961). Apparent cytoplasmic inheritance of tyrosinase competence in Streptomyces scabies. Nature, London 191, 465467.

Herbert, D., Phipps, P. J. \& Strange, R. E. (1971). Chemical analysis of microbial cells. Methods in Microbiology 5B, 242-344.

Hermodson, M. A., Ericsson, L. H., Titani, K., Neurath, H. \& WALSh, K. A. (1972). Application of sequenator analysis to the study of proteins. Biochemistry 11, 4493-4502.

Hopwood, D. A. (1967). Genetic analysis and genome structure in Streptomyces coelicolor. Bacteriological Reviews 31, 373-403.

HütTER, R. (1967). Systematik der Streptomyceten. Basel: Karger Verlag.

hütter, R., Kieser, T., Crameri, R. \& HintermanN, G. (1981). Chromosomal instability in Streptomyces glaucescens. In Proceedings, International Symposium on Actinomycete Biology, pp. 551-559. Edited by G. Pulverer \& K. P. Schaal. Stuttgart: Gustav Fischer Verlag.
KIESER, T. E. (1979). Untersuchungen von genetisch instabilen Eigenschaften in Streptomyces glaucescens. Thesis no. 6473 , Eidgenössische Technische Hochschule Zürich, Switzerland.

Kocher, H. P. (1976). Tyrosinase bei Streptomyces glaucescens. Regulation der Enzymsynthese. Ausscheidung des Enzyms. Thesis no. 5668, Eidgenössische Technische Hochschule Zürich, Switzerland.

KÜSTER, E. (1976). Chromogenicity of actinomycetes. In Actinomycetes: the Boundary Microorganisms, pp. 43-54. Edited by T. Arai. Tokyo: Toppan Co.

Lerch, K. \& Ettlinger, L. (1972). Purification and characterization of a tyrosinase from Streptomyces glaucescens. European Journal of Biochemistry 31, $427-437$.

MARX, J. L. (1980). Newly made proteins zip through the cell. Science 107, 164-167.

MendeZ, E. \& LAI, C. K. (1975). Regeneration of amino acids from thiazolinones formed in the Edman degradation. Analytical Biochemistry 68, 47-53.

Minuth, W., Kuischies, M. \& Esser, K. (1978). The phenoloxidases of the ascomycete Podospora anserina: structural differences between laccases of high and low molecular weight. European Journal of Biochemistry 90, 73-82.

Pisano, J. J., Bonzert, T. J. \& Brewer, H. B., JR (1972). Advances in the gas chromatographic analysis of amino acid phenyl- and methylthiohydantoins. Analytical Biochemistry 45, 43-59.

SUTER, M. A. (1978). Isolierung und Charakterisierung von Melanin-negativen Mutanten aus Streptomyces glaucescens. Thesis no. 6276, Eidgenössische Technische Hochschule Zürich, Switzerland.

Weber, K. \& Osborn, M. (1969). The reliability of molecular weight determinations by dodecyl sulfatepolyacrylamide electrophoresis. Journal of Biological Chemistry 244, 4406-4412. 